\title{
AN ASSESSMENT OF THE QUALITY OF SERVICES OFFERED BY THE NAŁĘCZÓW HEALTH RESORT AND SPA SA
}

\author{
EWA SKOWRONEK, ${ }^{1}$ ANDRZEJ TUCKI, ${ }^{2}$ MONIKA JODŁOWSKA ${ }^{3}$
}

Uniwersytet Marii Curie-Skłodowskiej

Wydział Nauk o Ziemi i Gospodarki Przestrzennej

${ }^{1}$ e-mail: ewa.skowronek@poczta.umcs.lublin.pl

2 e-mail: andrzej.tucki@umcs.pl

${ }^{3}$ e-mail:monika.jodlowska@o2.pl

\section{JEL CODES}

KEYWORDS

ABSTRACT
Z32

health tourism, the Importance-Performance Analysis [IPA] method, healthcare resorts' offer, quality of services, Health Resort and SPA Nałęczów SA

The paper presents the assessment of individual components comprising the offer of the Nałęczów Health Resort and SPA SA. The study stays within the vein of research into competitiveness of health tourism products. Highly topical, such investigations are more and more often described in both national and international research papers. The findings are very useful for entrepreneurs as they may be applied in business practice.

The analysis included the components of the ambience and attractiveness of the resort and services it offers. Two cohorts underwent the analysis - paying customers (commercial, paying in full) as well as the non-commercial referred to the resort by the national healthcare system [NFZ] and their social insurance [ZUS].

The research involved collecting the clients' opinions on their expectations concerning the services and the offer provided by the Nałęczów Resort and SPA. Their expectations were subsequently juxtaposed against the impressions they received using their products.

It was possible to identify strong and weak points of the offer owing to the Importance-Performance Analysis [IPA] method that focused of on customers' perception. Additionally, the findings allowed to specify strategic actions to be aimed at streamlining the company's performance. The most urgent activities to be undertaken include improving infrastructure and facilities (especially sanitary facilities and the equipment used for providing healthcare services). Furthermore, commercial tourists brought up the problem of a weak flexibility in matching healthcare services to customers' individual needs. 


\section{Introduction}

"Nałęczów Health Resort SA" healthcare institution is among the most dynamically growing Polish health resorts. The company's offer and range of services have been constantly evolving since its privatisation in 2002. The resort's development and the improvements of its competitive edge have made Nałęczów a multi-purpose centre whose performance was modelled on Western resorts. Its facilities cater for healthcare, tourism, sport, recreation and relaxation, thus supporting all forms of health tourism and related services (Skowronek, Krukowska, Tucki, 2012).

Activities that the Healthcare Institution has undertaken to date have been aimed at preparing a modern healthcare product which caters to the widest possible range of needs of a contemporary health tourist. These activities were in line with the strategy of competing against other Polish health resorts by diversifying the offer, matching the offer to various expectations and an improved flexibility. The quality of the services offered has also been scrutinised recently, which complies with the general assumption that it is only those health tourism resorts that provide highest quality of services that stand a chance of succeeding. High quality must be maintained across all components of the service, as well as the whole service package and the very place where the service is provided (Burzyński, Dryglas, Golba, Bartosik, 2005, p. 58).

A necessity to maintain and raise the quality of the health resorts' offer is a direct result of an increase in the share of commercial clients in the pool of services provided to all customers. Such customers provide ever increasing profits to resorts, however, unlike traditional customers referred to by the national healthcare system, commercial clients have greater financial means, but less time which they can spend relaxing. They also have slightly different expectations about their stay. According to W. Deluga (2013, p. 80), commercial customers expect cutting edge treatment facilities, high quality specialists and a guarantee of an atmosphere conducive to their treatment and relaxation. This group of customers also values highly: the quality of the hotel room equipment and treatment facilities, appropriate presentation of such facilities, staff's qualifications as well as ambience which is created to cater for healthcare customer's needs.

Hadzik and Szromek (2013, p. 101) expressed similar opinions concerning customers' expectations while presenting the criteria for the customers to assess Upper Silesian health resorts. They enumerate the following elements as important assessment criteria: the condition of the equipment and facilities, looks of the staff, trustworthiness (keeping appointments and reliability); meeting guests' needs, competency; empathy. Foreign literature presents similar criteria (inter alia Smith, Puczkó, 2009; Puczkó, 2010; Blešić et al. 2014).

In order to maintain high quality services, a constant assessment of the consumers' satisfaction levels is necessary, along with meeting their functional or non-functional needs, which was pointed out by Rapacz A. (1999), Burzyński et al. (2005), Panasiuk ed. (2007); Maciąg (2010); Batyk (2012); Hadzik, Szromek (2013).

This paper stays in the vein of research into products and quality of services offered by healthcare institutions as well as SPA and wellness companies offering their services on the market of broadly defined health tourism (Vogt, Pforr, 2013). Similar problems are tackled by Snoj, Mumel, 
(2002) Deng, (2007), Hadzik, Szromek, (2013) Środa-Murawska, Grzelak-Kostulska, Biegańska, (2015) Albayrak, Caber, Bideci (2016).

The paper aims at evaluating the quality of services offered by the "Nałęczów Health Resort SA" healthcare institution with the IPA method. The components of the atmosphere and attractiveness of the resort and the services it provides were analysed pursuant to the concept of competitiveness of the tourist destination by Buhalis (2000). Opinions from two cohorts were taken into account - customers who paid their fees in full (commercial) and those referred to the resort by the national healthcare system [NFZ] and their social insurance [ZUS] (non-commercial).

The problem of assessing attractiveness of the company as well as the quality of services it provides has already been tackled by Tucki, Hadzik (2013) and Mazurek-Kusiak, Soroka (2014). However, the aforementioned authors employed different methods. Only a few papers in Polish literature of the subject feature discussions of IPA's results employed for assessing services in resorts (see Środa-Murawska et al., 2015). This paper is in the vein of research projects aimed at the quality of resorts' offers.

\section{Material and research methods}

The article presents findings from original investigations obtained through the diagnostic poll method employing a poll questionnaire. The first leg of the research consisted in administering a pilot study in May 2016, including in-depth interviews (IDI). Based on these interviews and pursuant to the literature (Deng, 2007; Olbrych, Łopyta, 2011; Hadzik, Szromek, 2013; Szromek, 2013; Środa-Murawska et al., 2015), a selection of features was made to undergo respondents' final assessment.

The survey was conducted in the Nałęczów Health Resort (SE Poland) between summer and winter 2016. 70 questionnaires were used to collect data from SPA customers. There were two sections in each questionnaire. Section 1, consisting of eight questions, focused on respondents' personal (demographic) data. Section 2 collected respondents' opinions on the quality of the product offered by the Nałęczów Health Resort. The former section employed a 5-point Likert scale with 28 attributes of the importance and the performance of a product quality. The total of 50 questionnaires were ready for the use in data analysis at the end of the survey period. The piloting research on which this paper was based determined a relatively small number of the cohort that was analysed. Furthermore, the chi-square $\left(\chi^{2}\right)$ test investigated whether there were statistically significant differences in assessments of individual attributes made by commercial and non-commercial customers.

The Importance Performance Analysis [IPA] method was used to assess the guests' satisfaction with the services and the comprehensive product of the Nałęczów Health Resort SA. The model used was originally created by John A. Martill and John C. James in the late 70s (Krok, 2011). Relatively common, the method is employed across numerous businesses and branches of industry, including tourism, where it has been used to assess the quality of services offered in travelling (Oh, 2011), hospitality, gastronomy (Lai, Hitchcock, 2015), as well as in health resorts and SPA and wellness destinations (e.g. Snoj, Mumel, 2002; Deng, 2007; Środa-Murawska et al., 2015). 
An attempt was made at assessing the quality of services by the Nałęczów resort on the basis of the investigation by Środa-Murawska et al., (2015). The research process was appropriately modified so as to broaden the range of elements to be analysed (in total 28). Furthermore, the system of matrices that was adopted differed from the one presented by the aforementioned authors and instead was modelled on works by Blešić et al. (2014) and Niemiec (2015).

The IPA method plots satisfaction as a function of two components: an importance/rank of features of a given product and its quality as perceived by a customer. An importance and an assessment resulting from a customer's own experience was specified for each attribute separately. The measurements of individual attributes were made on a 5-point Likert's ordinal scale (1-5). A significance matrix was created for the resort's offer on the basis of average results and was subsequently divided with horizontal and vertical lines (activity framework/IPA) into four sections A, B, C, D (Figure 1). Taking the resort's viewpoint, section A seems the most worrying. Elements included in this section require prompt improvements. All activities focused on solving these problems ought to have a high priority as these are elements of high significance for a customer but generating low satisfaction with services. Section B includes elements which function appropriately, and need to be maintained (high significance/high level of satisfaction). Section C includes elements of low significance for the functioning of the resort's offer (low significance/low level of satisfaction). Finally, section D is believed to include elements where the offer functions appropriately but the factors it includes do not need a lot of attention (Blešić et al., 2014; Niemiec, 2015).

Administering this analysis facilitated identifying strong and weak points of the offer and services being provided. The findings allow to choose general directions for strategic actions aimed at streamlining resort's performance. Nevertheless, one must exercise caution while interpreting research findings from the piloting investigation.

\section{Results}

\section{Sample characteristics}

The research cohort was comprised of 50 tourists visiting Nałęczów, $48 \%$ of whom were males (24) and 52\% were females (26). The highest percentage were middle-aged (61-70 years) - 46\% of the respondents. Those aged from 71-90 made up 30\% of the research cohort. Younger health tourists in the age bracket of 41-60 accounted for merely $20 \%$ of the cohort, and the youngest generation, i.e. those below 30 were the minority of $4 \%$ ( 2 people).

Nearly a half - i.e. $46 \%$ of the respondents had secondary education, and there was also a considerable percentage of customers with higher education $-30 \% .18 \%$ had vocational education and only $6 \%$ had primary education.

$80 \%$ of the respondents were retired, followed by $14 \%$ of those with their own businesses. Finally, 6\% worked in the public sector.

Nearly half of the respondents (44\%) had a total household income ranging from 1,000 to 2,000 PLN (net). 12\% of the cohort had a relatively high income of 4,000 PLN and more, most of whom were the elderly. Nearly every fifth respondent (22\%) had an income ranging from 2,001 
to 3,000 PLN. There was also a relatively high percentage $(16 \%)$ of respondents with the lowest income, (i.e. below 1,000 PLN).

Investigated customers came from various communities. Respondents from towns of 50 to 100 thousand inhabitants predominated $-30 \%$ of the cohort. Shares of customers from big cities (with over $1 \mathrm{~m}$ inhabitants) and customers with rural background were similar - respectively $18 \%$ and $16 \%$. Respondents coming from small towns (up to 10,000 inhabitants) made up $12 \%$ of the cohort, which was identical to the percentage of the customers coming from towns of 10 to 50 thousand inhabitants. The shares of customers from cities of 100 to 500 thousand inhabitants and 0.5 to $1 \mathrm{~m}$ inhabitants were respectively $4 \%$ and $8 \%$.

Commercial customers who funded their own stay made up $58 \%$ of the cohort, whereas noncommercial customers made up the remaining $42 \%$ (referred by the national healthcare system [NFZ] and by their social security [ZUS]).

\section{Results of the Importance Performance Analyses (Overview of the resullts)}

The research consisted in obtaining customers' opinions on expectations concerning services and offer provided by the Resort Nałęczów, and then comparing these opinions with their experience while and after using the resort's offer. On the one hand, juxtaposing 28 attributes of the of the offer using the IPA characteristics allowed to assess customers' impressions concerning the importance of respective attributes. On the other hand, findings that were obtained are of primary importance for the company management as well as for those directly providing the services, as they constitute the feedback showing guests' perception of the resort.

Table 1 and Figures 1-3 present research results concerning highlighted attributes of the offer. They were presented as general opinions and later split into commercial customers and customers referred to the resort by the national healthcare system [NFZ] and social security [ZUS] (described as non-commercial patients - hence no answers to questions 13 and 21).

Research findings show that it is No. 14 (Cleanliness), No. 15 (Condition of sanitary fixtures and fittings), No. 20 (A level of matching healthcare services to customers' needs), No. 25 (Friendly attitude of the lodgings' staff), and 26. (Reliability in meeting obligations resulting from the healthcare offer) that constituted the group of elements for which customers had highest expectations. Therefore, the management and the marketing divisions ought to make every effort to improve these particular aspects of the product.

On the other hand, the lowest importance mean scores for all respondents were attributes No. 6 (Sports and recreation offer in the resort) and No. 5 (Cultural offer in the resort) in ascending order. These findings confirm that conditions of the stay as well as treatment and rehabilitation procedures are more important for customers than a diversified offer aimed at making their free time more attractive (see Środa-Murawska et al., 2015, 120). The importance of the remaining 21 attributes ranged from 3.98 to 4.60 . 
Table 1. Importance-Performance scores

\begin{tabular}{|c|c|c|c|c|c|c|c|c|c|}
\hline \multirow{2}{*}{$\begin{array}{l}\stackrel{0}{E} \\
\stackrel{\Xi}{E} \\
\stackrel{E}{Z}\end{array}$} & \multicolumn{3}{|c|}{ Total } & \multicolumn{3}{|c|}{$\begin{array}{l}\text { Commercial } \\
\text { Respondents }\end{array}$} & \multicolumn{3}{|c|}{ Non-Commercial Respondents } \\
\hline & $\begin{array}{c}\text { I } \\
\text { mean }\end{array}$ & $\begin{array}{c}\mathrm{P} \\
\text { mean }\end{array}$ & Gap & $\begin{array}{c}\mathrm{I} \\
\text { mean }\end{array}$ & $\begin{array}{c}\mathrm{P} \\
\text { mean }\end{array}$ & Gap & $\begin{array}{c}\mathrm{I} \\
\text { mean }\end{array}$ & $\begin{array}{c}\mathrm{P} \\
\text { mean }\end{array}$ & Gap \\
\hline 1. & 4.20 & 4.02 & -0.18 & 4.32 & 4.04 & -0.28 & 4.08 & 4.00 & -0.08 \\
\hline 2. & 4.32 & 4.24 & -0.08 & 4.56 & 4.36 & -0.20 & 4.08 & 4.12 & 0.04 \\
\hline 3. & 4.12 & 4.14 & 0.02 & 4.36 & 4.20 & -0.16 & 3.88 & 4.08 & 0.20 \\
\hline 4. & 4.24 & 4.28 & 0.02 & 4.44 & 4.52 & 0.08 & 4.04 & 4.04 & 0.00 \\
\hline 5. & 3.82 & 3.94 & 0.12 & 3.76 & 3.80 & 0.04 & 3.88 & 4.08 & 0.20 \\
\hline 6. & 3.74 & 3.80 & 0.06 & 4.00 & 3.92 & -0.08 & 3.48 & 3.68 & 0.20 \\
\hline 7. & 3.96 & 4.08 & 0.12 & 3.96 & 4.08 & 0.12 & 3.96 & 4.08 & 0.12 \\
\hline 8. & 4.62 & 4.32 & -0.30 & 4.56 & 4.32 & -0.24 & 4.68 & 4.32 & -0.36 \\
\hline 9. & 4.20 & 4.02 & -0.18 & 4.68 & 4.36 & -0.32 & 3.72 & 3.68 & -0.04 \\
\hline 10. & 4.06 & 3.98 & -0.08 & 4.20 & 2.28 & -1.92 & 3.92 & 3.68 & -0.24 \\
\hline 11. & 4.04 & 3.90 & -0.14 & 4.36 & 4.20 & -0.16 & 3.72 & 3.60 & -0.12 \\
\hline 12. & 3.98 & 3.98 & 0.00 & 4.24 & 4.16 & -0.08 & 3.72 & 3.80 & 0.08 \\
\hline 13. & 4.28 & 4.60 & 0.32 & 4.28 & 4.16 & -0.12 & $\mathrm{n} / \mathrm{a}$ & $\mathrm{n} / \mathrm{a}$ & $\mathrm{n} / \mathrm{a}$ \\
\hline 14. & 4.74 & 4.56 & -0.18 & 4.84 & 4.64 & -0.20 & 4.64 & 4.48 & -0.16 \\
\hline 15. & 4.70 & 3.54 & -1.16 & 4.68 & 4.12 & -0.56 & 4.72 & 2.96 & -1.76 \\
\hline 16. & 4.6 & 4.00 & -0.60 & 4.60 & 4.12 & -0.48 & 4.60 & 3.88 & -0.72 \\
\hline 17. & 4.54 & 4.30 & -0.24 & 4.48 & 4.36 & -0.12 & 4.60 & 4.24 & -0.36 \\
\hline 18. & 4.24 & 4.36 & 0.12 & 4.40 & 4.28 & -0.12 & 4.08 & 4.44 & 0.36 \\
\hline 19. & 4.06 & 4.38 & 0.32 & 4.16 & 4.32 & 0.16 & 3.96 & 4.44 & 0.48 \\
\hline 20. & 4.60 & 4.30 & -0.30 & 4.60 & 4.24 & -0.36 & 4.60 & 4.36 & -0.24 \\
\hline 21. & 4.44 & 3.92 & -0.52 & 4.44 & 3.92 & -0.56 & $\mathrm{n} / \mathrm{a}$ & $\mathrm{n} / \mathrm{a}$ & $\mathrm{n} / \mathrm{a}$ \\
\hline 22. & 4.60 & 4.58 & -0.02 & 4.68 & 4.60 & -0.08 & 4.52 & 4.56 & -0.04 \\
\hline 23. & 4.58 & 4.62 & 0.04 & 4.68 & 4.44 & -0.24 & 4.48 & 4.80 & 0.32 \\
\hline 24. & 4.52 & 4.50 & -0.02 & 4.72 & 4.56 & -0.16 & 4.32 & 4.44 & 0.12 \\
\hline 25. & 4.64 & 4.74 & 0.10 & 4.88 & 4.60 & -0.28 & 4.40 & 4.88 & 0.48 \\
\hline 26. & 4.62 & 4.38 & -0.24 & 4.68 & 4.40 & -0.28 & 4.56 & 4.36 & -0.20 \\
\hline 27. & 4.42 & 4.62 & 0.20 & 4.64 & 4.48 & -0.16 & 4.20 & 4.76 & 0.56 \\
\hline 28. & 4.50 & 4.48 & -0.02 & 4.56 & 4.48 & -0.08 & 4.44 & 4.48 & 0.04 \\
\hline
\end{tabular}

Note: I - Importance; P - Performance.

Attributes:

1. Location/journey to the resort. 2. Resort's ambience and image. 3. Availability and quality of information on the resort's services and offer. 4. Spring park and buildings' arrangement. 5. Cultural offer in the resort. 6. Sports and recreation offer in the resort. 7. Tourist offer. 8. A wide offer of treatment therapies available in the resort. 9. Look of the premises/venue/SPA buildings. 10. Roominess of the lodgings. 11. Equipment in the lodgings. 12. Number of people per room. 13. Price of the accommodation. 14. Cleanliness. 15. Condition of sanitary fixtures and fittings. 16. Condition of the facilities and equipment used to provide healthcare services. 17. Food quality. 18. Diversity of the meals. 19. Optional diets. 20. A level of matching healthcare services to customers' individual needs. 21. Total cost for the whole stay. 22. Competence of doctors and other medical staff as well as their attitude to patients. 23. Services and competence of the lodgings' staff. 24. Friendly attitude of the medical staff. 25. Friendly attitude of the lodgings' staff. 26. Reliability in meeting obligations resulting from the healthcare offer. 27. Approachability of the medical staff. 28. The level of understanding customers' needs in the domain of providing healthcare services.

Source: own study based on the findings from the poll questionnaire.

Performance assessments were relatively high. The mean score for the whole cohort of respondents averaged out at 4.24 for the 28 components being analysed, which is a good result for the 
company. No. 25 (Friendly attitude of the lodgings' staff), No. 23 (Services and competence of the lodgings' staff. and No. 27 (Approachability of the medical staff), i.e. attributes connected with the human factor, scored highest -4.47 and 4.62 . The lowest score was given to No. 15 (Condition of sanitary fixtures and fittings) - merely 3.54 (Table 1).

Analysing the discrepancies in the assessment of importance and performance, the authors found as many as 16 performance mean scores to be lower than corresponding importance mean scores. They were ascribed negative values of the indicators (Table 1). This shows that the quality of the product of the Nałęczów Resort and SPA comes across slightly worse than the guests' expectations, which is worrying.

The greatest discrepancies between expectations and impressions of services provided were recorded in cases of attributes No. 15 (Sanitary fixtures and fittings), No. 16 (Condition of the facilities and equipment used to provide healthcare services), No. 21. (Total cost for the whole stay), No. 13 (Price of the accommodation), No. 19 (Optional diets), No. 8 (A wide offer of treatment therapies available in the resort), No. 20 (A level of matching healthcare services to customers' individual needs). These findings are crucial for the management as they prove there is an urgent need to modernise the premises and facilities. Customers were also dissatisfied with restricted opportunities to make their own diet choices, select treatments, and with catering for their individual healthcare needs.

On the other hand, customers were positively surprised with 11 attributes, among which it was No. 27 (Approachability of the medical staff), No. 5 (Cultural offer in the resort), No. 7 (Tourist offer), No. 18 (Diversity of the meals), and No. 25 (Friendly attitude of the lodgings' staff) that were perceived best.

Merely one assessment element precisely matched customers' expectations - values of Importance and Performance indicators were identical in case of No. 12 (Number of people per room). Obviously, this was because respondents knew in advance about their accommodation.

Taking the abovementioned data into account, one must match them with the significance/ achievement matrix. Analysing Section A (Concentrate Here), which requires particular attention from the resort staff responsible for the functioning of the offer, it becomes clear that it is features No. 15 (Condition of sanitary fixtures and fittings), No. 16. (Condition of the facilities and equipment used to provide healthcare services), and No. 21 (Total cost for the whole stay) that require urgent action on the part of the company (Figure 1).

Group B (Keep up the Good Work) - i.e. elements that function adequately (high significance/ high satisfaction level) include: $8,14,17,20,22,23,24,25,26,27,28$ - i.e. treatment offer, food, high competence of the staff, and medical staff's adequate approach to patients and other employees.

Features 1, 3, 5, 6, 7, 9, 10, 11, 12 have low significance for the functioning of the resort's offer (low significance/ low satisfaction level). They are situated in Section C (Low Priority).

Features No. 2 (Resort's ambience and image), No. 4 (Spring park and buildings' arrangement), No. 13 (Price of the accommodation), No. 18 (Diversity of the meals), and No. 19 (Optional 
diets), (Figure 1) are all situated in Section D (Possible Overkill), where the offer functions adequately, however, only little attention needs to be paid to these factors.

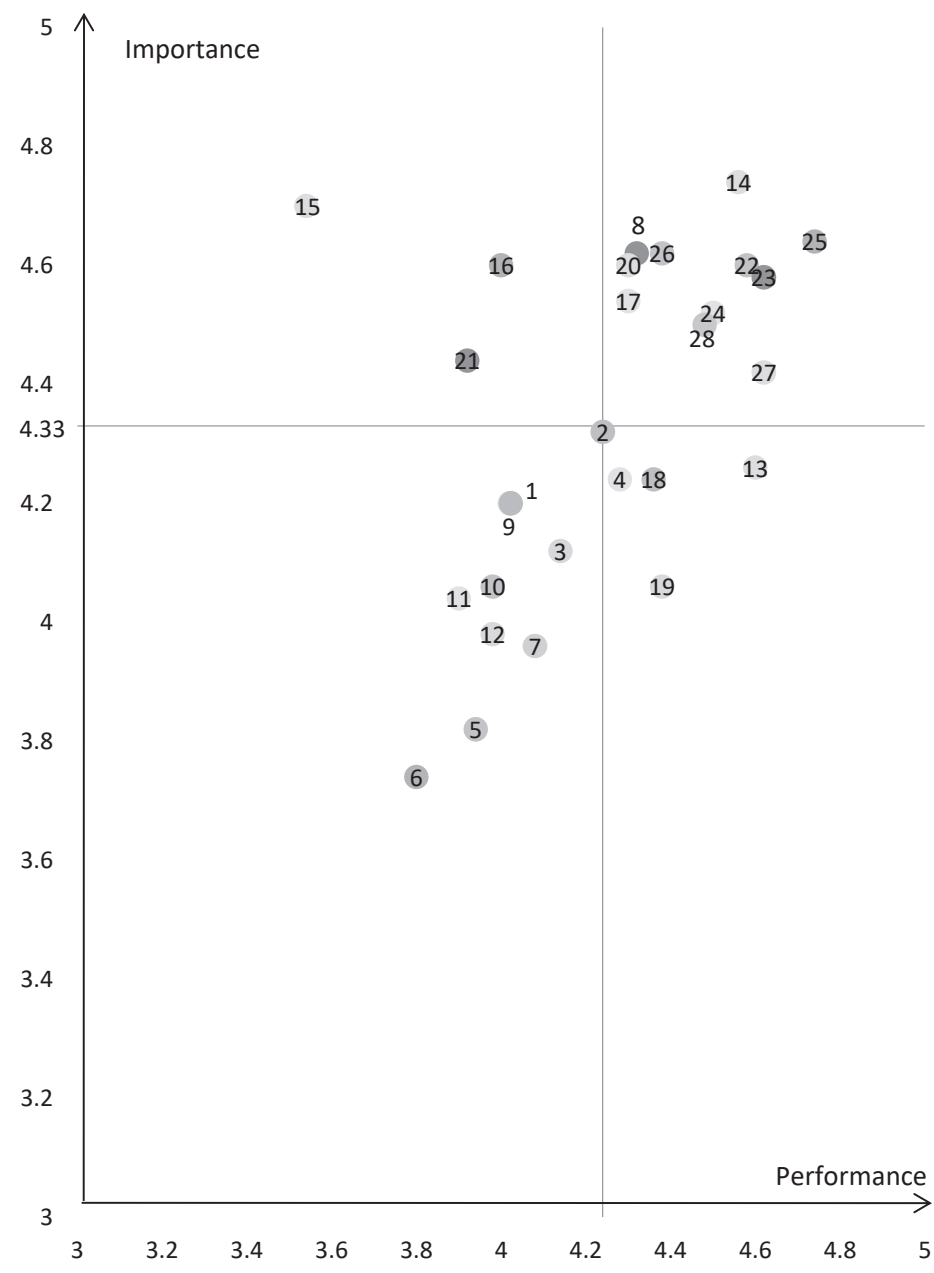

Mean: Importance - 4.33; Performance - 4.24.

See the explanation on the meanings of attributes below Table 1.

Figure 1. IPA - satisfaction with the product and services of the Nałęczów Health Resort (total)

Source: author's own research.

According to the research premise, the findings were also juxtaposed in respective groups of respondents. The way of funding the stay was the major criterion for the division. Responses suggest that customers paying for the stay themselves (so called commercial clients) averagely give more importance to a significant majority of features of the health resort's product. However, their subjective assessments of respective elements of the offer's performance are significantly better 
than those made by non-commercial customers (Table 1). This phenomenon is also confirmed by the mean for the whole group - 4.21 (Figure 2), which is some positive feedback for the company.

Merely 8 out of the total of 28 attributes were assessed lower by fully paying customers. These were components: 5, 10,18, 19, 20, 23, 25, 27, and decidedly lowest assessment was attributed to feature No.10 (Roominess of the lodgings) -2.28 .

On the positive side, components No. 14. (Cleanliness), No. 22 (Competence of doctors and other medical staff as well as their attitude to patients), No. 25 (Friendly attitude of the lodgings' staff), No. 24 (Friendly attitude of the medical staff), and No. 4 (Spring park and buildings' arrangement), (Table 1) were perceived best by the commercial customers of the resort.

A disturbing phenomenon requires attention at this point. Customers' expectations were higher for most attributes (i.e. 24) in the cases of the quality of services and offer components. This phenomenon manifests itself with negative values of differences between mean Importance and Performance. It was only in the cases of attributes No. 4 (Spring park and buildings' arrangement), No. 5 (Cultural offer of the resort), No. 7 (Tourist offer), and No. 19 (Optional diets) that commercial customers were positively surprised (the Performance assessment was higher than an attribute's Importance).

According to commercial customers, the following attributes demand considerable improvements (Figure 2, Section A): No. 15 (Condition of sanitary fixtures and fittings), No. 16 (Condition of the facilities and equipment used to provide healthcare services), and No. 20 (A level of matching healthcare services to customers' individual needs).

Customers referred to the resort by the national healthcare system [NFZ] and their social insurance [ZUS] gave different answers. In comparison to commercial customers, this group averagely paid less importance to the great majority of investigated features of the healthcare product, which means they had fewer expectations concerning the offer. In this group, higher assessments of importance were only recorded with respect to four features: No. 5 (Cultural offer in the resort), No. 8 (A wide range of treatment therapies available in the resort), No. 15 (Condition of sanitary fixtures and fittings), and No. 17 (Food quality) (Table 1). Furthermore, non-commercial customers showed greater dissatisfaction with services they obtained, which is indicated by the lower mean assessment of Performance -4.16 .

Merely 8 out of 28 attributes were assessed better/higher than commercial customers. The components with higher assessments were: No. 5 (Cultural offer in the resort), No. 10 (Roominess of the lodgings), No. 18 (Diversity of the meals), No. 19 (Optional diets), No. 20 (A level of matching healthcare services to customers' individual needs), No. 23 (Services and competence of the lodgings' staff), No. 25 (Friendly attitude of the lodgings' staff), No. 27 (Approachability of the medical staff).

In this group of respondents, it is the assessment of attribute No. 15 (Condition of sanitary fixtures and fittings) that was most worrying in the context of customers' expectations juxtaposed with the resort's offer. This assessment had the lowest value out of all elements being analysed 2.96 (Table 1). 


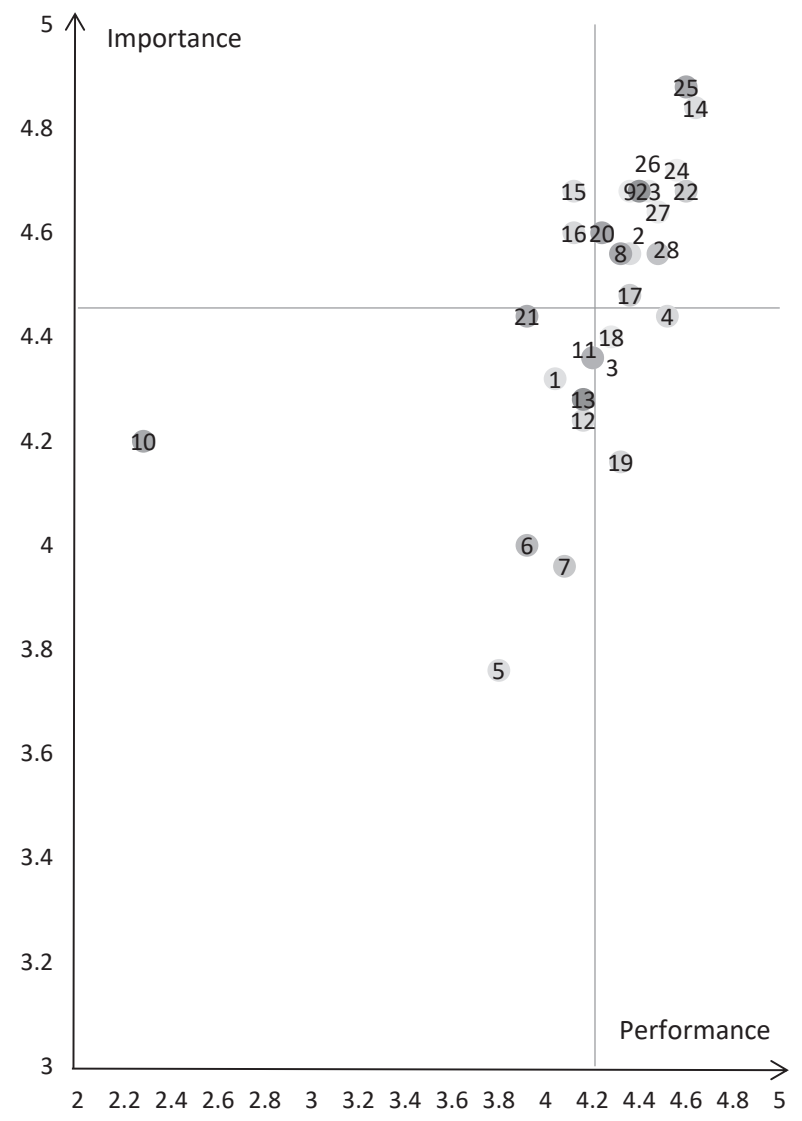

Mean: Importance - 4.46, Performance - 4.21.

See the explanation on the meanings of attributes below Table 1.

Figulu 2. IPA - satisfaction with the product and services of the Nałęczów Health Resort (commercial users)

Source: author's own research.

On the other hand, attribute No. 23 (Services and competence of the lodgings' staff) obtained highest assessment within this group -4.8 .

Unlike commercial customers, those whose stay was funded by the national healthcare system [NFZ] or social insurance [ZUS] were rather positively surprised by their stay in the resort. Negative values of the difference between mean Importance and Performance were recorded in the cases of merely 12 attributes, which was a half of the number in the group of commercial customers (24 negative values). Non-commercial customers were disappointed with the following components of the offer 1, 8, 9, 10, 11, 14, 15, 16, 17, 20, 22, 26. The highest negative values within this group were attributed to: No. 15 (Condition of sanitary fixtures and fittings), No. 16 (Condition of the facilities and equipment used to provide healthcare services), and No. 26 (Reliability in meeting obligations resulting from the healthcare offer) (Table 1). 


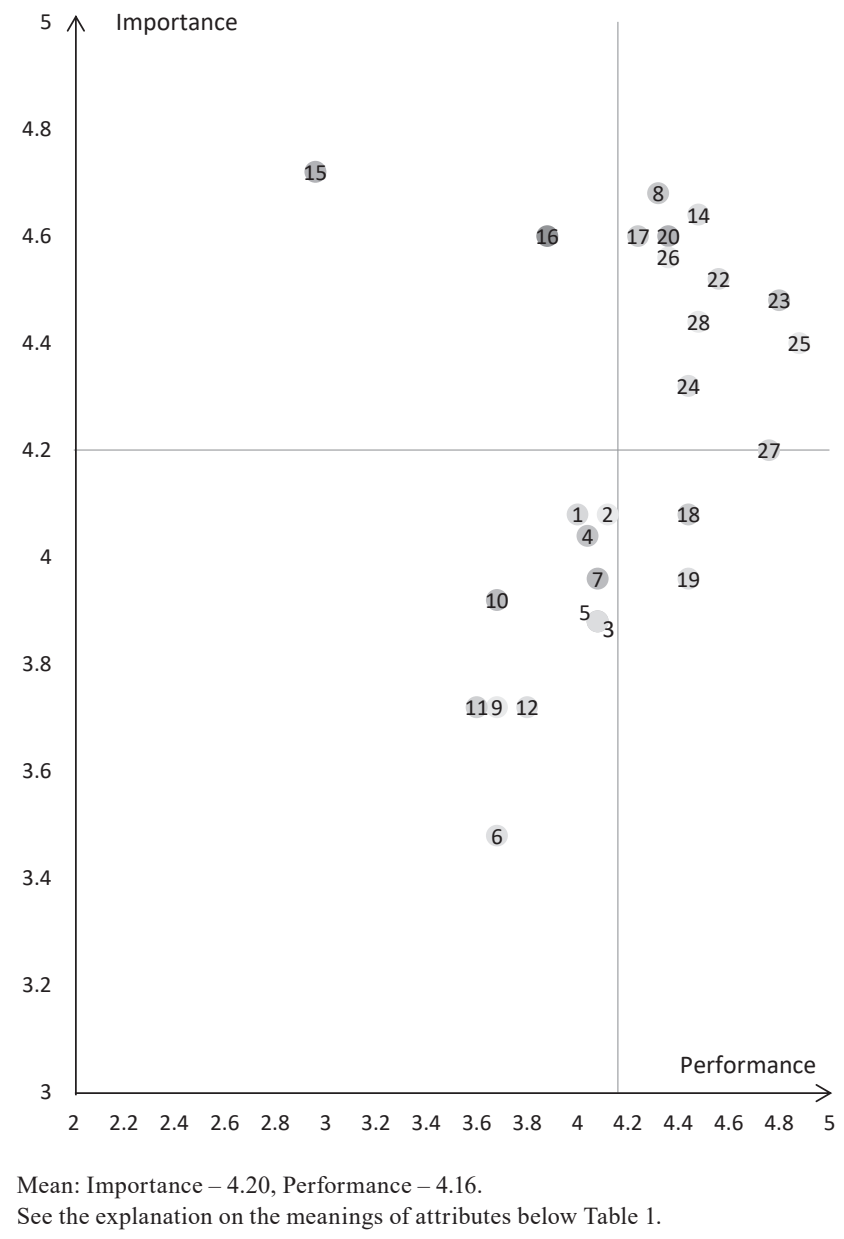

Figure 3. IPA - satisfaction with the product and services of the Nałęczów Health Resort (non-commercial users).

Source: author's own research.

Attributes No. 15 (Condition of sanitary fixtures and fittings), No. 16 (Condition of the facilities and equipment used to provide healthcare services) require urgent action according to non-commercial customers (Figure 3, Section A), which is similar to impressions of commercial customers.

\section{Conclusions}

Nałęczów Health Resort and SPA SA is currently one of the leading Polish health resorts. Its actions to date have aimed at preparing a modern health resort product, and in recent years more and more attention is being paid to the quality of services being provided. 
The analysis of the resort's offer included components of the ambience and attractiveness of the venue and the services. The study focused on the two groups of service recipients - commercial customers and non-commercial customers (referred to by their national healthcare system [NFZ] and their social insurance [ZUS]).

The differences in quality assessments of individual offer attributes of the Nałęczów resort made by commercial and non-commercial customers proved to be statistically insignificant $(\mathrm{p}=0.038)$.

Mean assessments of the quality of components in both cohorts of resort visitors were relatively high - respectively 4.21 and 4.16 , which proves that the company has prepared an attractive product for its customers. This is in line with the conclusions by Tucki and Hadzik (2013), who found the resort to be highly attractive. However, the offer requires constant streamlining and undertaking several urgent actions.

Detailed opinion analyses proved commercial customers to have higher expectations about the offer's components, yet they also assessed the product better than the customers referred to by the national health service [NFZ] and their social insurance [ZUS]. This suggests that the commercial offer is more attractive and better prepared than that aimed at customers referred to by the healthcare and insurance institutions.

The respondents paying for their stay appreciated the attractiveness of the venue (the spring park and buildings' arrangement), an opportunity to select an appropriate diet, cleanliness as well as the competence and the friendly attitude of the staff. On the other hand, they were dissatisfied with the roominess of their lodgings, cultural offer, sports and recreation, and with the total price of the product. This opinion reflects the conclusions of Środa-Murawska et al. (2015). Responses by commercial customers staying in the Ciechocinek resort were similar in good assessments of the medical offer and staff competence, however, poorer assessments were made of the cultural offer and entertainment.

It must be stressed that for this group of respondents, the differences between assessments of importance and performance of respective components were negative for most attributes (24). This may suggest that the customers were not really satisfied with their stay. Their expectations were better than the actual product.

Non-commercial customers had lesser expectations about the resort's offer, and it was the cultural offer, a range of available treatments, the state of sanitary fixtures and fittings as well as the quality of food that they found most important. They expressed their lower satisfaction with the services in their lower assessments. It was the state of sanitary fixtures and fittings, as well as the equipment used to provide healthcare services that they found to be the greatest problem. On the other hand, services and competence of the staff were the qualities that they appreciated most. According to the findings by Środa-Murawska et al. (2015), non-commercial customers from Ciechocinek also made highest assessments for medical services and the competence of the staff, while the lowest evaluations were made for the cultural offer, entertainment opportunities and cleanliness. 
In contrast to commercial customers, respondents whose stay was funded by the national healthcare system [NFZ] and their social insurance [NFZ] were rather positively surprised during their stay in the resort. Negative values of differences between assessments occurred merely in the cases of 12 attributes.

Using the IPA method has allowed to recognise strong and weak points of the offer and services provided by the resorts. Research findings allowed to pinpoint most important problems that customers notice and to show directions for actions that need to be taken for the company to function appropriately. The most urgent actions include improvements in the state of infrastructure and equipment (especially sanitary fixtures and fittings as well as the equipment used for performing healthcare services). Furthermore, commercial tourists pay more attention to the problem of flexibility in matching healthcare services to customers' individual needs.

The assessments of the quality of services offered by the Nałęczów Health Resort SA were made on the basis of the piloting investigation, hence the findings are not definitive. However, they might be useful guidelines as the study has significant implications both for practitioners and academics. From the management's perspective, our results may provide a clear guidance for the improvement of the tourist offer by identifying the main area of intervention according to tourists' perceptions.

\section{Translated by Konrad Dejko}

\section{Referenences}

Albayrak, T., Caber, M., Bideci, M. (2016). Identification of Hotel Attributes for Senior Tourists by Using Vavra's Importance Grid. Journal of Hospitality and Tourism Management, 29, 17-23.

Batyk, I.M. (2012). Diagnoza determinantów wpływających na jakość usług turystycznych. Zarządzanie i Finanse, 1 (3), 291-304.

Blešić, I., Popov-Raljić, J., Uravić, L., Stankov, U., Đeri, L., Pantelić M., Armenski, T. (2014). An importance-performance analysis of service quality in spa hotels. Economic Research-Ekonomska Istraživanja, 1 (27), 483-495. DOI: 10.1080/1331677X.2014.967537.

Buhalis, D. (2000). Marketing the competitive destination of the future. Tourism Management, 1 (21), 97-116.

Burzyński, T., Dryglas, D., Golba J., Bartosik, A. (2005). Czynniki wplywające na jakość i konkurencyjność usług turystycznych $w$ miejscowościach uzdrowiskowych. Kraków: Instytut Turystyki w Krakowie Sp. z o.o., Stowarzyszenie Gmin Uzdrowiskowych RP.

Deluga, W. (2013). Konkurencja jako czynnik podwyższania jakości usług sanatoryjnych. Zeszyty Naukowe Uniwersytetu Szczecińskiego, 784, Ekonomiczne Problemy Turystyki, 3 (23), 73-96.

Deng, W. (2007). Using a revised importance-performance analysis approach: The case of Taiwanese hot springs tourism. Tourism Management, 5 (28), 1274-1284. Retreived from: http://dx.doi.org/10.1016/j.tourman.2006.07.010.

Hadzik, A., Szromek, A.R. (2013). Ocena jakości usług prozdrowotnych świadczonych przez górnośląskie uzdrowiska. Zeszyty Naukowe Uniwersytetu Szczecińskiego, 784, Ekonomiczne Problemy Turystyki, 3 (23), 99-106.

Krok, E. (2011). Jakość usług medycznych. Studies \& Proceedings of Polish Association for Knowledge Management, $38,98-107$.

Lai, I., Hitchcock, M. (2015). Importance performance analysis in tourism: A framework for researchers. Tourism Management, 48, 242-267.

Maciąg, J. (2010). System zarządzania jakościa usług: zasady i metody (na przykładzie ustug turystycznych i rekreacyjnych). Katowice: Wydawnictwo AWF.

Martilla, J., James, J. (1977). Importance-Performance Analysis. Journal of Marketing, 1 (41), 77-79. 
Mazurek-Kusiak, A.K., Soroka, A. (2014). Ocena jakości usług w przedsiębiorstwie uzdrowiskowym Nałęczów SA. Ekonomika i Organizacja Przedsiębiorstwa, 3, 78-89.

Niemiec, A. (2015). Możliwość zastosowania analizy istotności-osiągnięć w identyfikacji i ewaluacji zestawu kluczowych mierników dokonań (KPIs). Zeszyty Naukowe Uniwersytetu Szczecińskiego, 873, Finanse, Rynki Finansowe, Ubezpieczenia, 77, 563-572. DOI: 10.18276/frfu.2015.77-57.

Oh, H. (2001). Revisiting importance-performance analysis. Tourism Management, 22, 617-627.

Olbrych, B., Łopyta, B. (2011). Technika IPA jako narzędzie oceny satysfakcji pacjentów w jednostkach ochrony zdrowia. Studies \& Proceedings of Polish Association for Knowledge Management, 38, 175-190.

Panasiuk, A. (ed.) (2007). Jakość ustug turystycznych. Szczecin: Wydawnictwo Naukowe Uniwersytetu Szczecińskiego.

Puczkó L. (ed.) (2010). Health, Wellness and Tourism: healthy tourists, healthy business? Proceedings of the Travel and Tourism Research Association Europe Annual Conference. Travel and Tourism Research Association Europe. Dalarna, Sweden.

Rapacz, A. (1999). Jakość sposobem konkurencji przedsiębiorstw i regionów turystycznych. In: G. Gołembski (ed.), Rozwój ustug turystycznych u progu XXI wieku. Poznań: Wydawnictwo AE.

Skowronek, E., Krukowska, R., Tucki, A. (2012). Innowacyjność i rozwój oferty Uzdrowiska Nałęczów SA jako odpowiedź na zapotrzebowanie rynku turystyki zdrowotnej. Zeszyty Naukowe Uniwersytetu Szczecińskiego, 698, Ekonomiczne Problemy Ustug, 83, 495-508.

Smith, M., Puczkó, L. (2009). Health and Wellness Tourism. Oxford: Elsevier.

Snoj, B., Mumel, D. (2002). The measurement of perceived differences in service quality - The case of health spas in Slovenia. Journal of Vacation Marketing, 4 (8), 362-379.

Szromek, A.R. (2013). Cechy atrakcyjności polskich uzdrowisk. Zeszyty Naukowe Politechniki Ślaskiej, Organizacja i Zarzadzanie, 64 (1894), 251-264.

Środa-Murawska, S., Grzelak-Kostulska, E., Biegańska, J. (2015). Jakość usług oferowanych przez Uzdrowisko Ciechocinek w opinii kuracjuszy. Zeszyty Naukowe Uniwersytetu Szczecińskiego, 853, Ekonomiczne Problemy Turystyki, 2 (30), 109-124.

Tucki, A., Hadzik, A. (2013). Analiza możliwości rozwoju turystyki zdrowotnej w województwie lubelskim w kontekście zidentyfikowanej inteligentnej specjalizacji regionu $w$ dziedzinie ustug medycznych i prozdrowotnych. Lublin: Perfekta info.

Voigt, C., Pforr, C. (eds.) (2013). Wellness Tourism: A Destination Perspective. London: Routledge. 


\section{OCENA JAKOŚCI USŁUG OFEROWANYCH PRZEZ ZAKŁAD LECZNICZY UZDROWISKO NAŁĘCZÓW SA}

SŁOWA KLUCZOWE

STRESZCZENIE turystyka zdrowotna, metoda IPA, oferta uzdrowisk, jakość usług, uzdrowisko Nałeczów SA

Praca dotyczy oceny jakości składowych oferty świadczonej przez Zakład Leczniczy Uzdrowisko Nałęczów SA. Wpisuje się w nurt badań nad konkurencyjnością produktu turystyki zdrowotnej. Jest to aktualny problem, coraz częściej poruszany w krajowych i zagranicznych opracowaniach naukowych. Bardzo często wyniki takich prac są pomocne przedsiębiorcom, mają zatem zastosowanie praktyczne.

Analiza obejmowała składowe atmosfery i atrakcyjności kurortu oraz świadczonych w nim usług. Dotyczyła dwóch grup - klientów pełnopłatnych (komercyjnych) oraz skierowanych tam przez NFZ i ZUS (niekomercyjnych).

Istotą przeprowadzonych badań było uzyskanie od kuracjuszy opinii na temat oczekiwań odnośnie usług i oferty świadczonej przez uzdrowisko w Nałęczowie, a następnie porównanie ich z odczuciami, które uzyskali po, lub w trakcie konsumpcji.

Dzięki zastosowanej metodzie IPA możliwe było rozpoznanie mocnych i słabych stron oferty, wynikające z percepcji klientów. Uzyskane wyniki pozwoliły ponadto na określenie strategicznych działań, mających na celu właściwe funkcjonowanie przedsiębiorstwa. Do tych najpilniejszych należy zaliczyć poprawę stanu infrastruktury i urządzeń (zwłaszcza sanitarnych i tych wykorzystywanych do usług zdrowotnych). Ponadto turyści komercyjni zwrócili uwagę na problem niskiej elastyczności w dostosowywaniu usług zdrowotnych do indywidualnych potrzeb klienta. 